\title{
DIÁLOGOS CON LA REINA DE LOS CIELOS. VISIONES Y LOCUCIONES DE UNA MONJA CHILENA DEL SIGLO XVIII*
}

\author{
POR \\ René Millar Carvacho \\ Instituto de Historia \\ Pontificia Universidad Católica de Chile
}

\section{RESUMEN}

El artículo analiza un texto inédito escrito por una monja de Santiago de Chile, a mediados del siglo XVIII, por mandato de su confesor. En él se refieren las visiones y locuciones tuvo con la Virgen, las que giran en torno a la figura del confesor. Esto hace bastante especial el relato, pues el sacerdote aparece como un personaje central de las visiones, que se beneficia de la intercesión de la religiosa ante los seres celestiales. Pero al mismo tiempo, la narración deja en evidencia a una religiosa muy consciente de su papel, de sus limitaciones como mujer y de su poder mediador. Por otra parte, el relato de la monja muestra no sólo su manera de vivir la fe, sino también nos permite acercarnos a la mentalidad religiosa de su época.

Palabras Claves: Monja, visionaria, autobiografía, experiencias místicas, confesor

\section{DIALOGUES WITH THE QUEEN OF HEAVEN: VISIONS AND LOCUTIONS OF A CHILEAN NUN IN THE IGHTEENTH CENTURY}

\begin{abstract}
This article analyses an unpublished text written by a nun in Santiago of Chile around the mid-eighteenth century. The text, written by her confessor's command, recounts the visions and locutions that she had with the Virgin Mary, which
\end{abstract}

"Agradecemos al expresidente de la Academia Chilena de la Historia don José Miguel Barros Franco, actual poseedor del documento, el habernos facilitado el manuscrito original de la religiosa que nos permitió la elaboración de este artículo. 
revolved around the figure of the confessor. This makes quite a special report because the priest appears as a central character of the visions, and the one who benefits from the intercession of the nun before the heavenly beings. At the same time, the account gives evidence of the nun's awareness of her role, her limitations as a woman and her mediator power. On the other hand, the nun's narrative shows not only the way of living her faith, but also allows us to get nearer to the 'religious mentality' of her time.

KEY WORDS: Nun, visionary, autobiography, mystical experiences, confessor.

$\begin{array}{ll}\text { Recibido/Received } & \text { 25-10-2012 } \\ \text { Aceptado/Accepted } & \text { 04-12-2014 }\end{array}$

\section{UN MANUSCRITO INÉDITO}

El documento que analizaremos forma parte de un pequeño volumen que contiene cinco textos manuscritos, cuatro de ellos de temática religiosa, mientras que el restante se refiere a metalurgia. El más extenso, a pesar de ser una versión incompleta, es el primero y trata sobre profecías en las Sagradas Escrituras. Otros dos corresponden a sendos cuadernillos con métodos para practicar la oración contemplativa. En el volumen aparecen encuadernados juntos, como parte de un mismo tema. El que resta, es un escrito de una monja en el que relata sus experiencias místicas.

En ninguno de los textos aparecen sus autores y desconocemos también la fecha en que se escribieron, aunque el tipo de letra nos indica que, por lo menos estas versiones, son del siglo XVIII. El empaste del volumen es muy posterior, posiblemente de la segunda mitad del siglo xIX o comienzos del xx. En el lomo, con letras doradas, dice: Varios. Manuscritos. Profecía de la S. Escritura. Relaciones de un alma. Metalurgia. Algo sobre piedad. Además, en ese mismo sitio, está pegada una estampilla blanca, con las señas probables de la ubicación en la estantería de una biblioteca. De hecho, en el interior figura un ex libris, cuya tinta muy borrosa, indicaría en latín que pertenecía a la biblioteca del Seminario de Santiago.

Quien agrupó los textos para encuadernarlos, los separó colocándoles una hoja a modo de portadilla, en el que escribió un título para cada uno. Al de la monja lo denominó Revelaciones de una alma piadosa (sic). Este escrito tiene una extensión de 18 páginas, de un tamaño un poco menor a un octavo de folio y claramente corresponde a la versión original de él, como se desprende del tipo de letra, grafía, redacción y ortografía, que muestran a una persona sin mucho manejo práctico en esos ámbitos. Es muy probable que el texto haya sido redactado a mediados del siglo XVIII. La monja indica una fecha, pero su 
lectura no resulta fácil. Nosotros, teniendo en cuenta la gráfica de los números y el contexto que fluye de la relación, estimamos que el documento fue escrito en 1745. Parte del problema está en el tercer número de la cifra, que podría corresponder a un nueve o a un cuatro. Ante esas alternativas, nos inclinamos por la segunda debido a la relativa similitud entre el tercer número de esa cifra y la forma del número cuatro que aparece en otra página del escrito. A eso se agrega otro aspecto a considerar. En la última página, con letra del siglo XVIII, se menciona el nombre del propietario del folleto. Empero, el proceso posterior de encuadernación, borró buena parte de las palabras que indicaban esa información. De lo que queda, aparece con claridad el nombre propio «D[o] n Joseph de» y las siguientes palabras, truncadas algunas: «del Consejo de», «isimo obispo», «lesia Imperial», «iille» y «S[a]ntiago». ${ }^{1}$ Además, en el texto se señala que el confesor de la religiosa habría sido designado por esa época obispo, al parecer, de Concepción. Estos datos coinciden con los de José de Toro y Zambrano, designado titular de esa diócesis el 18 de diciembre de 1744, por el Papa Benedicto XIV. ${ }^{2}$ Por cierto que no tenemos certeza respecto de esas conclusiones e incluso hay indicios que nos hacen dudar, como el que los números que nos sirven de referencia para las comparaciones pudieron ser estampados, dada la coloración de la tinta, por una mano diferente a la que escribió el texto. También está el hecho de que José de Toro Zambrano, antes de su nombramiento episcopal, se desempeñaba desde hacía bastantes años como canónigo de la catedral de Santiago y no era frecuente que una dignidad fuese confesor de monjas.

De la autora tenemos una mínima información, que es la que se desprende del texto mismo. De partida desconocemos su identidad, aunque sí sabemos que se llamaba María. Tampoco tenemos información respecto a la edad que tenía al momento de escribir el texto, ni de la orden religiosa a la que pertenecía. Sin embargo, es muy probable que fuese una monja de velo negro; es decir, de aquellas que habían ingresado al convento pagando una dote y que gozaban del derecho a elegir a la superiora. Normalmente ese tipo de religiosas pertenecía a la elite social de la época y de hecho los conventos de clausura se habían erigido en el mundo hispanoamericano, en parte, para contribuir a la estabilidad social del grupo dirigente. No era fácil para una familia de la nobleza, con varias hijas, poderlas casar con sujetos de un nivel social equivalente o superior debido al coste de las dotes. De ahí que los conventos acogieran a las jóvenes

\footnotetext{
${ }^{1}$ Los obispos del período hispano al firmar un documento utilizaban entre otras la expresión «Del Consejo de Su Magestad» y el adjetivo «ilustrísimo».

${ }^{2}$ Oviedo Cavada, C. 1982. «La defensa del indio en el sínodo del obispo Azua de 1744», Historia, 17: 288. También Méndez Beltrán, L. M. 1992. «José Toro y Zambrano 1674 - 1745 - 1760», en C. Oviedo Cavada (Dir.), Episcopologio chileno 1561 - 1815. IV: 356. Santiago: Ediciones Universidad Católica de Chile. Toro y Zambrano tomó posesión de la diócesis de Concepción, a comienzos de 1746.
} 
con inquietudes religiosas y a las hijas de familia sin recursos suficientes para financiar varias dotes matrimoniales. ${ }^{3}$ Nuestra afirmación de que era una monja de velo negro se fundamenta en que tenía el cargo de portera, que sólo lo desempeñaba ese tipo de religiosa. ${ }^{4}$ A eso se une el que asistiera al coro a rezar. Las religiosas de velo negro también eran conocidas con la denominación de monjas de coro. Esto por la obligación que tenían de asistir a rezar regularmente las horas canónicas en dicho lugar.

\section{EXPERIENCIAS ESPIRITUALES}

El texto de la monja solo recoge sus experiencias espirituales. En consecuencia, no aporta ninguna información de carácter biográfico, pues su interés era muy específico: referir los favores sobrenaturales recibidos. Con todo, podría ser considerado una forma de relato autobiográfico, especial por cierto, pero digno de caber en un concepto amplio de ese tipo de escritos, el que podemos utilizar en la medida que en la Época Moderna aún no se distinguía con precisión entre los diferentes géneros literarios. ${ }^{5}$ En suma, el relato de esta monja anónima es muy diferente al de las otras dos religiosas chilenas del período español cuyos escritos se han publicado. Al de Úrsula Suárez lo es no sólo por la extensión sino también por el contenido. Esta religiosa, en su relación, siguiendo algunos paradigmas hagiográficos, entrega muchas referencias biográficas, desde su niñez hasta su etapa en el convento; también relata sus vivencias religiosas y aspectos de la vida cotidiana en el claustro. ${ }^{6}$ Igualmente se diferencia de los escritos de la monja Dolores Peña y Lillo, en la medida que ellos constituyen parte de la correspondencia que mantenía con su padre espiritual y que se generó a instancias de la religiosa. ${ }^{7}$ En todo caso, los tres escritos tienen un factor en común: el

${ }^{3}$ Lavrin, A. 2008. Brides of Christ. Conventual Life in Colonial Mexico: 18-25. California: Stanford University Press. Ibsen, K. 1999. Women's Spiritual Autobiography in Colonial Spanish America: 3-6. Gainesville: University Press of Florida.

${ }^{4}$ Ibídem: 132. Fernández, A.; Leiva, L.; Guerra, M. y Martínez, L. 1997. La mujer en la conquista y la evangelización en el Perú (Lima 1550-1650): 216-217. Lima: Pontificia Universidad Católica del Perú. Borda, Fr. A. de. 1708. Práctica de confesores de monjas, en que se explican los cuatro Votos de Obediencia, Pobreza, Castidad y Clausura, por modo de Diálogo: 13. México: Francisco de Ribera Calderón. Este autor señala que los oficios de portera, tornera y escucha deben desempeñarse aunque desagraden a las religiosas por que están contempladas en la Regla de la orden.

${ }^{5}$ Poutrin, I. 1995. Le voile et la plume. Autobiographie et sainteté féminine dans l'Espagne moderne: 18. Madrid: Casa de Velázquez. Ibsen, K. 1999: 10-11.

${ }^{6}$ Suárez, U. 1984. Relación autobiográfica. Santiago: Academia Chilena de la Historia. Ibse, K. 1999: 122-136.

${ }^{7}$ Kordić, R. (Ed.). 2008. Epistolario de Sor Dolores Peña y Lillo (Chile, 1763-1769). Frankfurt: Universidad de Navarra, Iberoamericana y Vervuert. Urrejola, B. 2006. «<Carísimo padre mío y toda mi estimación en Nuestro Señor>: Obstinación y afecto por el confesor en el epistolario de Josefa de los Dolores Peñailillo (Chile, s. XVIII)», Atenea 494.

Hispania Sacra, LXVII

135, enero-junio 2015,247-275, ISSN: 0018-215X, doi: 10.3989/hs.2015.007 
papel decisivo que en ellos juega la figura del confesor. Todavía más, en el caso de Úrsula Suárez y de nuestra monja, el escrito es consecuencia de un mandato imperativo del confesor, al que las religiosas se someten en cumplimiento de su voto de obediencia. ${ }^{8}$ Pero también los tres textos muestran la fuerte personalidad de sus autoras, que hacen gala de su autonomía frente a los confesores.

Cuando en la época, en el ámbito de las mujeres piadosas, tanto laicas como religiosas, se hablaba del confesor, no estaban refiriéndose solo al sacerdote que administraba el sacramento de la confesión. Apuntaban a alguien que iba más allá, a un sacerdote, de cierto prestigio y que en determinado momento podía ser un padre o madre, un corrector, un maestro o un director ${ }^{9}$, ante el cual la penitente buscaba consejo y abría su corazón, haciéndolo su confidente. Estos eran los padres espirituales o maestros de espíritu, que tomaron gran impulso después de Trento, guiando a los que buscaban la perfección, respondiendo a sus dudas e inquietudes y dando respaldo a sus experiencias sobrenaturales. ${ }^{10} \mathrm{La}$ generalidad de los escritos autobiográficos o de experiencias místicas efectuados por monjas de la Época Moderna se originan en órdenes expresas dadas por los respectivos directores espirituales. La historiadora francesa Isabelle Poutrin trabaja con los casos de más de 270 religiosas hispanas, cuyas autobiografías fueron ordenadas por sus confesores y que a veces se utilizaron para escribir las respectivas biografías o para postular sus causas a la santidad..$^{11}$ Los sacerdotes les pedían a algunas de sus hijas de confesión que pusieran por escrito sus autobiografías o vivencias religiosas cuando se daban determinadas circunstancias. Por ejemplo, si la monja había dado muestras de una vida espiritual muy rica y sobre todo si la práctica continua e intensa de la oración le había llevado a experimentar fenómenos sobrenaturales, tales como éxtasis, visiones, revelaciones o locuciones. Los directores espirituales perseguían objetivos diversos con ese mandato. Para muchos, el escrito era un útil instrumento para guiar a la religiosa por los complejos caminos de la oración contemplativa. A través de él iba viendo los avances o retrocesos que aquella podía experimentar en las

\footnotetext{
${ }^{8}$ Suárez, U. 1984: 90.

${ }^{9}$ Ranft, P. 1994. «A Key to Counter Reformation Women's Activism: The Confessor-Spiritual Director». Journal of Feminist Studies in Religion, Vol. 10, $\mathrm{N}^{\circ} 2: 10$.

${ }^{10}$ Bilinkoff, J. 2005. Related lives. Confessors and Their Female Penitents, 1450-1750: 17 y ss. Ithaca: Cornell University Press. . El fenómeno de las mujeres visionarias alcanzó un gran desarrollo en el ámbito hispano durante la Época Moderna. En esto influyó el Cardenal Cisneros, que publicó en castellano los escritos de las santas italianas Catalina de Siena y Ángela de Foligno y protegió a la monja Juana de la Cruz, famosa por sus visiones y revelaciones. No obstante la represión que experimentaron esas manifestaciones después de Trento, en el siglo XVII volvieron a tomar fuerza, en parte gracias a la canonización de Teresa de Ávila, que se transformó en uno de los modelos importantes de las visionarias de las tierras americanas. Arenal, E. \& Schlau, S. 1989. Untold Sisters. Hispanic Nuns in Their Own Works: 8-11. Alburquerque: University of New Mexico Press. Lavrin, A. 2005. «La madre María Magdalena Lorravaquio y su mundo visionario», Signos Históricos 13: 22-41.

${ }^{11}$ Poutrin, I. 1995: 8-9 y 421-467. Bilinkoff, J. 2005: 5-6, 27-28, 47-48.
} 
diferentes fases de ese método de oración. Debe tenerse presente que el auge de los escritos autobiográficos está estrechamente asociado al fuerte impulso que experimentó la mística en el mundo católico del sur de Europa a raíz de la reforma que llevaron adelante las órdenes religiosas desde fines del siglo Xv. ${ }^{12}$ Habría contribuido también a ese fenómeno el reconocimiento que numerosos teólogos hicieron de la posibilidad efectiva de que ciertas mujeres gozaran de favores divinos. ${ }^{13}$ Gran acogida encontró entre religiosas y beatas la búsqueda de Dios a través de expresiones afectivas, específicamente del amor ${ }^{14}$. Esa forma de espiritualidad llevó al desarrollo de los métodos de la oración contemplativa, que hacían necesaria la guía o conducción por un experto dadas las dificultades que planteaban. Fueron los jesuitas los que más se destacaron, a partir de los Ejercicios Espirituales, en la conceptualización del fenómeno contemplativo, en la elaboración de manuales y de métodos de oración que llevaran a un encuentro con Dios. ${ }^{15}$

Pero paralelamente, el auge de la mística favoreció la aparición de prácticas heterodoxas al plantearse por algunos que, a diferencia de lo sostenido por Santo Tomás, la contemplación era un don gratuito de Dios, sin que cupiera intervención humana. ${ }^{16}$ Ese parecer fue sostenido, entre otros, por los alumbrados, que decían alcanzar la unión con Dios y por lo tanto la perfección espiritual, manteniendo quietas o negando las potencias del alma, es decir el entendimiento, la memoria y la voluntad. ${ }^{17}$ La Inquisición reaccionó con dureza, tratando de evitar la propagación de esa corriente, que era asociada al reformismo protestante y que, en algunos casos, llevó a desenfrenos sexuales con el argumento de estar libre de pecado por haberse alcanzado la perfección. ${ }^{18}$ En consecuencia, el

${ }^{12}$ Poutrin, I. 1995: 28-31. Muriel, J. 1994. Cultura femenina novohispana: 313 y ss. México: Universidad Autónoma de México, destaca la relación entre las escritoras místicas españolas y la abundante producción de escritos espirituales de las mujeres novohispanas.

${ }^{13}$ Haliczer, S. 2002. Between Exaltation and Infamy. Female Mystics in the Golden Age of Spain: 58-59. New York. Oxford University Press.

${ }^{14}$ Lehfeldt, Elizabeth A. 2005. Religious Women in Goldewn Age Spain. The permeable cloister: 201-214. Hampshire. Ashgate.

${ }^{15}$ En ese sentido sobresalen especialmente Francisco Suárez, Alonso Rodríguez y Luis de la Puente. Jean Krynen, J. 1990. Saint Jean de la Croix et l'aventure de la mystique espagnole: 255 y ss. Toulouse: Presses Universitaires du Mirail. France-Iberie Recherche.

${ }^{16}$ Poutrin, I. 1995: 52. Santo Tomás postulaba que el conocimiento de Dios se alcanza por obra de la razón y de la gracia. Suma Teológica. P. I, c. 12.

${ }^{17}$ Márquez, A. 1980. Los alumbrados. Orígenes y filosofía (1525-1559): 169 y ss. Madrid: Taurus Ediciones. Andrés, M. 1994. Historia de la mística de la Edad de Oro en España y América: 274 y ss. Madrid: Biblioteca de Autores Cristianos.

${ }^{18}$ Huerga, A. 1978 y 1994. Historia de los Alumbrados. I.- Los Alumbrados de Extremadura (1570-1582): Introducción y cap. II. Historia de los alumbrados. V.- Temas y personajes (1570-1630): cap. I y II. Madrid: Fundación Universitaria Española. Andrés, M. 1984. «Alumbrados, erasmistas, «luteranos» y místicos, y su común denominador: el riesgo de una espiritualidad más «intimista», en Alcalá, A. (Ed.), Inquisición española y mentalidad inquisitorial: 373 y ss. Barcelona: Ariel.

Hispania Sacra, LXVII

135, enero-junio 2015,247-275, ISSN: 0018-215X, doi: 10.3989/hs.2015.007 
misticismo fue visto con ojos críticos por ciertos sectores de la Iglesia al asociársele a esos movimientos heréticos. A lo anterior se sumó la aparición de diversos casos de falsa santidad femenina ${ }^{19}$. Ocurrió que algunas beatas y monjas aparentaron haber alcanzado la perfección espiritual, a la vez que decían gozar de dones sobrenaturales, que les permitían el contacto con la divinidad y percibir y conocer hechos y situaciones que escapaban a los ojos corporales. Hubo más de un incidente que generó gran conmoción en su tiempo, como el de la monja impostora de Portugal avalada nada menos que por Fr. Luis de Granada. ${ }^{20}$ Todas esas situaciones contribuyeron a que la figura del director espiritual adquiriera una gran significación. Él, con su prudencia y sabiduría, debía evitar que la religiosa cayera bajo la influencia del demonio, que le podía presentar falsas visiones o tentarla exaltando su soberbia y ambición. En ese proceso, los escritos de las experiencias espirituales de las monjas y beatas eran fuentes básicas para el discernimiento de los espíritus, es decir para poder determinar si las visiones y revelaciones tenían un origen divino o demoníaco. ${ }^{21}$

Por último, los escritos autobiográficos también fueron utilizados como testimonios para fundamentar la postulación a la santidad de la autora. El texto autobiográfico mismo o la biografía realizada a partir de él, muchas veces por el propio confesor, constituyeron el punto de partida de un proceso que culminará con la formalización de una causa de beatificación. ${ }^{22}$ Para un confesor en particular y para la orden religiosa a la que pertenecía era muy importante, por razones de prestigio, el poder presentar a la comunidad estos modelos de virtud, que ellos habían podido encauzar. ${ }^{23}$ En esos casos, el confesor aparecía avalando la perfección espiritual del sujeto, el ejercicio heroico de las virtudes cristianas, el origen divino de las visiones reseñadas y el disfrute de otros dones sobrenaturales.

Respecto del texto que nos convoca, ignoramos la identidad y demás antecedentes biográficos del confesor que ordenó a la monja ponerlo por escrito.

\footnotetext{
${ }^{19}$ Haliczer. S. 2002: 55.

${ }^{20}$ Alcalá, A. 1984. «Control de espirituales», en Pérez Villanueva, J. y Escandell Bonet, B. Historia de la Inquisición en España y América: 808. Madrid: BAC. Haliczer, S. 2002: 53-54, plantea que existió una preocupación por las nuevas formas de espiritualidad practicadas por las mujeres debido a que limitaban la autoridad masculina tanto en el ámbito familiar como dentro de la Iglesia, lo que habría llevado a ésta a controlar las manifestaciones de religiosidad popular y a ser más cuidadosa respecto de las visiones, revelaciones y otras expresiones de santidad femenina.

${ }^{21}$ Poutrin, I. 1995: 106-114. Lavrin, A. 2012. «La religiosa y su confesor. Epistolario de una clarisa mexicana, 1801-1802», Archivium, Franciscanum Historicum, An. 105: 470.

${ }^{22}$ Lavrin, A. y Loreto, R. (Eds.). 2002. Monjas y beatas. La escritura femenina en la espiritualidad barroca novohispana. Siglos XVII y XVIII: 8. México: Universidad de las Américas. Puebla y Archivo General de la Nación. Poutrin, I. 1995: 20-21.

${ }^{23}$ Millar Carvacho, R. 2009. Santidad, falsa santidad y posesiones demoníacas en Perú y Chile. Siglos XVI y XVII. Santiago: Ediciones Universidad Católica de Chile.
} 
Algunas mínimas referencias a su persona en el desarrollo del relato nos permiten inferir que se llamaba José ${ }^{24}$ y que se trataba de un clérigo secular. De acuerdo a lo ya señalado, se insinúa que habría aspirado al cargo de obispo. Por cierto que ese dato no es determinante, pero en el siglo XVIII la gran mayoría de los nombramientos diocesanos recaían en sacerdotes seculares. Otra mención que se hace del confesor, no necesariamente relacionada con la anterior, tiene que ver con un traslado a una ciudad que podría ser Concepción, a la que se alude diciendo que tiene «por título el misterio que tú amas». Como lo indicamos al comienzo, tendemos a suponer, con las reservas del caso, que el confesor pudo haber sido José de Toro y Zambrano.

\section{FORMAS Y CONTENIDOS}

El breve texto está estructurado en cinco partes, numeradas, que no marcan materias diferentes sino ciertas fases cronológicas del relato. ${ }^{25}$ Fue redactado en primera persona y pensado para ser expuesto por escrito. No se trata de un relato oral que se va escribiendo, como ocurre en otros textos de religiosas o beatas. La narración sigue la secuencia que habrían tenido las experiencias sobrenaturales de la monja y el estilo es directo, dejando entrever numerosas faltas ortográficas y de configuración de las palabras. La caligrafía es pareja dentro de una cierta rusticidad, lo que la aleja un poco de la imagen que presenta el común de los manuscritos de la época; la forma de las letras es un tanto irregular y las palabras, en su escritura, con frecuencia aparecen separadas. La narración se estructura en gran medida en forma dialógica entre la protagonista-escritora y la visión que se le aparece de manera preferente. Esta es la Virgen, a la que la monja se refiere como «mi Señora», «mi Madre», «Mamita» o «mi Reina». Se le aparecía cuando estaba rezando en su celda o en el coro y le hablaba en forma coloquial. De hecho, la Virgen la trata de «hija» o simplemente la llama por su nombre: «María».

En suma, en el texto, la monja expone los encuentros y diálogos que habría tenido con la Virgen durante algunos meses de su vida conventual, los que se relacionaban con una determinada temática. Nada se dice más allá de ese corto período, por lo que no sabemos desde cuando gozaba de esos dones. Los fenómenos extraordinarios que experimentaba correspondían a visiones místicas, es decir, a percepciones de carácter sobrenatural de fenómenos u objetos que por naturaleza no pueden ser observados por los ojos. Paralelamente, la religiosa

\footnotetext{
${ }^{24}$ Millar Carvacho, R. 2009. Santidad, falsa santidad y posesiones demoníacas en Perú y Chile. Siglos XVI y XVII. Santiago: Ediciones Universidad Católica de Chile.

${ }^{25}$ Es posible que la numeración, dada la coloración de la tinta y los trazos de los números, no haya sido efectuada por la misma mano que escribió el texto.

Hispania Sacra, LXVII

135, enero-junio 2015,247-275, ISSN: 0018-215X, doi: 10.3989/hs.2015.007
} 
entraba en comunicación verbal con la Virgen, lo que en el ámbito de la espiritualidad corresponde a las denominadas locuciones. Estas eran voces o expresiones orales de la divinidad o de un ser celestial que un sujeto podía percibir por medio de la imaginación, los sentidos o el intelecto. ${ }^{26}$ Estas clases de manifestaciones sobrenaturales podían ser experimentadas por aquellas personas que habían llegado a los niveles más altos de la contemplación mística. ${ }^{27}$

Las visiones y locuciones de las que da cuenta la monja María tienen por protagonista a la Virgen, que le transmite diversos mensajes relacionados con su padre confesor. Por lo mismo, la figura de dicho sacerdote constituye el centro de la trama que gira en torno a esos fenómenos sobrenaturales. De acuerdo al relato, la Virgen se le habría presentado un día, a fines de enero de 1745, mientras se encontraba rezando, comunicándole que quería «disponer» a su confesor para una pesada enfermedad que, por determinación de su Hijo, debía padecer por tres meses. Además se le hacía notar a la monja que también debía preparar su voluntad para aceptar ese golpe. A los pocos días ese mensaje se confirmaría, pues la religiosa se enteró que efectivamente su confesor habría caído en cama enfermo. A partir de ese momento, todos los encuentros con la Virgen giran en torno a la situación del sacerdote, que la monja trata de revertir con ruegos a su esposo Jesucristo y a su Madre ${ }^{28}$, en los que alude a la labor que aquél había realizado como salvador de almas y a la posibilidad de asumir ella la enfermedad en reemplazo de su padre espiritual. En las locuciones se explicita el motivo por el cual Cristo había decidido imponer ese sufrimiento al sacerdote. De acuerdo con esos mensajes, se trataría de un medio que utilizó para tratar de despertarlo «del letargo en que le tiene la esperanza de ser príncipe» ${ }^{29}$; en otras palabras puede interpretarse como la aplicación de un castigo por una ambición exagerada.

Las súplicas habrían tenido efecto, pues la monja logró que la sanción recayera en ella, liberando al sacerdote. De hecho, la Virgen le habría comunicado que estaría enferma durante un mes, como efectivamente aconteció, eximiendo así a su director espiritual. Este no sólo resultaría exculpado sino que además,

\footnotetext{
${ }^{26}$ Borriello, L., Caruana, E., Del Genio, M.R. y Suffi, N. 2002. Diccionario de mística. Madrid: Editorial San Pablo.

${ }^{27}$ Puente, L. de la. 1897 (1609). Meditaciones espirituales: I, 93-98. Barcelona: Imprenta y Librería de Subirana Hermanos.

${ }^{28}$ No era raro que las monjas en sus encuentros místicos con los seres celestiales intercedieran por su confesor, afectado por algún problema. Así lo efectúa Gertrudis de San Idelfonso, monja de Santa Clara, Quito Ecuador, ver «La perla mística escondida en la concha de la humildad», en Rossi de Fiori, María; Caramella de Gamarra, Rosanna; Martínez de Lecuona, Soledad y Fiori Rossi, Helena, 2008. La palabra oculta. Monjas escritoras en la Hispanoamérica colonial: 434-435. Salta, Argentina: Universidad Católica de Salta, Editorial de Textos Universitarios.

${ }^{29}$ Revelaciones de una alma piadosa. Punto 1.
} 
de acuerdo con las locuciones, Cristo terminó por recompensar su labor caritativa eligiéndole «pastor de las almas» y, al parecer, destinándolo a la ciudad de Concepción, que requería ser enderezada, en palabras de la Virgen.

En las visiones también aparecen otros personajes del mundo celestial. En la parte final del texto, coincidiendo con el día de San José, figura con cierto relieve la Sagrada Familia: la Virgen, San José y el Niño que tendría entre dos y tres años, los cuales consuelan a la monja con sus misericordias en un momento en que se encuentra enferma ocupando el lugar de su confesor. En la relación de sus experiencias, la monja menciona además las visiones que experimentó de unos seres que denomina compañeros y que correspondían a lo que considera cuatro virtudes: la caridad, el amor, la obediencia y el temor, que la Virgen se las presenta para que la «enseñasen y apartasen de los riesgos». No dejan de ser peculiares estas visiones, en la medida que personifican de manera separada el amor y la caridad, le reconocen un valor especial a la obediencia y al temor le dan el rango de virtud. Por último, la monja refiere experiencias con las almas del Purgatorio. En el relato dice que las vio al profesar y después detalla la visión de una determinada alma en pena por largo tiempo, a la que pudo apreciar saliendo de su condena gracias, en parte, a la acción caritativa de su confesor.

IMÁGENES Y PALABRAS

\section{Visiones y locuciones}

Las visiones y locuciones de esta monja, en el contexto de la oración contemplativa, dan cuenta de una determinada mentalidad y de ciertas actitudes que van más allá del caso particular, reflejando creencias y comportamientos que formaban parte del imaginario religioso y de las conductas asociadas a él que se expresaron en el ámbito hispano de la Época Moderna. En primer lugar está la creencia en la realidad de esas manifestaciones sobrenaturales. Como lo hemos señalado, entre las beatas y religiosas abundaban las visionarias y sus experiencias eran avaladas por el medio en el que se desenvolvían y por los religiosos que las dirigían espiritualmente. Esto ocurría porque se vivía en un ambiente en que el mundo natural y el sobrenatural tendían a superponerse y se tenía asumida la creencia de que era normal que Dios o los demás seres de la corte celestial comunicaran a los hombres sus intenciones y determinaciones, por lo general centradas en un marco de recompensas y sanciones. La oración contemplativa favorecía el encuentro con la divinidad. De hecho el objetivo de ella era lograr la unión del alma con Dios, instancia en la cual se podían producir 
esos fenómenos extraordinarios..$^{30}$ De acuerdo a la teología mística, no cualquier sujeto podía llegar a las instancias superiores de la oración y tampoco por ende gozar de aquellos dones. Tales experiencias estaban reservadas a personas excepcionales y, por lo mismo, quienes los conocían les daban la consideración de persona santa.

María, la monja de este texto, percibía las visiones y locuciones cuando rezaba y, a veces, encontrándose en un estado de semiinconsciencia. Ella alude a esa situación diciendo que estaba «como dormida o fuera de mi», por lo que podemos inferir que se arrobaba con mucha facilidad, lo cual era frecuente entre las místicas visionarias. Los prodigios que percibe están en función de su confesor, que, como hemos visto, fue quien le ordenó ponerlos por escrito. Y aquí, nos encontramos con una situación peculiar. El confesor le impone esa obligación, al parecer, sabiendo ya el contenido de aquellos, al punto que el texto comienza con las siguientes palabras: «Vuestra Señoría me manda asiente lo que ya le tengo comunicado». En la primera parte de este artículo vimos los objetivos que perseguían los confesores al mandar escribir las experiencias espirituales a las monjas. En este caso, esos fines no se expresan con claridad y por el contrario da la impresión de que el sacerdote perseguía un interés particular, como era el realzar su figura, que aparecía premiada por la divinidad. Los eclesiásticos cuando más buscaban prestigiarse como directores de espíritu por encauzar la religiosidad de una mujer santa. En este caso, el texto gira casi exclusivamente en torno al confesor y no hay una relación de otras experiencias espirituales o de vida de la religiosa. ${ }^{31}$ Aquí pareciera que se pretende presentar una designación episcopal como producto de la acción divina directa. De ser José de Toro Zambrano el protagonista, debe considerarse que su postulación al obispado de Concepción se había efectuado en octubre e 1744 y que su designación se realizó el 18 de diciembre de ese año. ${ }^{32}$ Es muy factible que en los primeros días de 1745, al escribirse este texto, se tuvieran aquí en Santiago noticias de aquellas determinaciones, que pudieron llegar a oídos de la religiosa y que, dado el

\footnotetext{
${ }^{30}$ Lavrin, A. 2005: 32.

${ }^{31}$ La aparición del confesor en visiones de su hija espiritual, contada en sus escritos, se puede encontrar en otros casos, como por ejemplo en el de la madre María de San José del convento de Santa Mónica de Puebla de los Ángeles y después de otro en Oaxaca. En su diario espiritual la monja consigna una visión y locución con Nuestro Señor en la que ve a su confesor en su ascenso al cielo después de muerto, por haber sido un gran director de almas. También aparece ella intercediendo ante el Señor por la salud de su confesor. Con todo, esas son menciones y apariciones aisladas en un contexto de decenas de páginas en los que da referencias biográficas, informa sobre la vida conventual y relata con minuciosidad sus experiencias espirituales, que se centran en sus visiones y locuciones, ver Myers, K.A. and Powell, A. (Eds). 1999. A wild country out in the garden. The Spiritual Journals of a Colonial Mexican Nun: 86-87. Bloomington: Indiana University Press.

${ }^{32}$ Oviedo Cavada, C. 1979. Los obispos de Chile 1561-1978: 182-183. Santiago: Editorial Salesiana.
} 
especial estado psicológico que vivía en los momentos de oración, se transformaron en el motivo de las locuciones.

\section{Obediencia al confesor}

El relato de la monja muestra con claridad su preocupación por cumplir acertadamente con el mandato de su confesor; la ejecución de lo ordenado le produce una tensión, al igual como acontece con muchas de las monjas que escriben sus experiencias a instancias de sus directores espirituales. ${ }^{33}$ Tenía dudas respecto de la manera como debía proceder en la ejecución de lo mandado e, inquieta por no dilatar el cumplimiento, optó, solicitando iluminación celestial, por escribir lo comunicado por la Virgen sin esperar explicaciones. En otra parte del texto volvió a tocar el tema de la obediencia y lo hizo dejando de manifiesto que le habían mandado no ocultar lo que no era suyo, es decir, que debía exponer lo que la Virgen le refería acerca de la forma como el Señor favorecía «a las almas que escoge para sí». ${ }^{34}$ Aquí vemos otra vez, la preocupación del confesor para que la monja pusiera por escrito los favores que el Señor le había dispensado. El voto de obediencia de las religiosas, al igual que en el caso de los religiosos, formaba parte de la observancia de la regla y de las constituciones de la orden, y estaba íntimamente asociada a la virtud de la humildad, lo que implicaba renunciar a sus ambiciones y reconocer sus limitaciones. Se enfatizaba la obediencia a los superiores eclesiásticos, vale decir a la abadesa, en razón de la potestad dominativa que poseían, ${ }^{35} \mathrm{y}$ a los prelados, vicarios y confesores, quienes gozaban de jurisdicción espiritual. ${ }^{36}$ La obediencia a los superiores se derivaba de la que se le debía a Dios, quien premiaba con su amor a la monja que cumplía con esa obligación, otorgándole incluso el privilegio de la unión mística. ${ }^{37}$ En lo que toca a las monjas hay una preocupación especial de las autoridades eclesiásticas por enfatizar la obligatoriedad e importancia de ese voto. Así el jesuita Antonio Núñez, señalaba en México, en 1679, en una plática con motivo de la profesión religiosa de una monja que, respecto de la obediencia, «convienen todos los

\footnotetext{
${ }^{33}$ Donahue, D. 1989. «Writing Lives: Nuns and confessors as auto/biographers in Early Modern Spain». Journal of Hispanic Philology 13: 235.

${ }^{34}$ Revelaciones..., op. cit., punto 2.

${ }^{35}$ Borda, Fr. Andrés de. 1708: 10 y ss. Por cierto que el cumplimiento cabal del voto de obediencia al interior de los claustros a veces era relativo. Un ejemplo de ello es el comportamiento de la monja Josefa Dolores Peñailillo, al respecto ver Urrejola, B. op. cit.

${ }^{36}$ Bravo Arriaga, D. 2001.El discurso de la espiritualidad dirigida. Antonio Núñez de Miranda, confesor de Sor Juana: 51. México: Universidad Nacional Autónoma de México. La jurisdicción espiritual era la que entregaba potestad al sacerdote para, en calidad de juez, absolver los pecados del penitente.

${ }^{37}$ Lavrin, L. 1993.«La vida femenina como experiencia religiosa: biografía y hagiografía en Hispanoamérica colonial», Colonial Latin American Review, 2: 29.
} 
Teólogos, con Santo Thomas y los Místicos con los Santos Padres, que es el principal de todos; y como la forma y constitución última de la Religión que por ello se llama vida de obediencia». ${ }^{38}$ Nuestra religiosa tenía tan asumida la importancia de ese voto que nada menos que una de las cuatro virtudes que la Virgen le había asignado para su protección y guía era la obediencia.

El voto solemne de obediencia implicaba «la absoluta y perpetua abdicación de la propia voluntad».$^{39}$ Esta cuestión ha suscitado una de las preocupaciones centrales de los estudios sobre las autobiografías espirituales de las religiosas, la cual tiene que ver con la autonomía de las autoras con respecto al mandante..$^{40}$ La mayoría de los estudios tienden a reconocer que, a pesar del control ejercido por los confesores, las autoridades eclesiásticas y la Inquisición, y más allá de la rigideces formales que poseían, esos escritos reflejaban la individualidad de la religiosa ${ }^{41} \mathrm{El}$ texto que analizamos pareciera que contradice ese planteamiento, pues no sólo obedece al mandato del confesor, sino que el contenido lo tiene a él como un actor central y el objetivo aparentemente es su beneficio. Con todo, más allá de las ponderaciones a su persona, que justificarían la recompensa, en el relato se hace una crítica expresa a las ambiciones del confesor. ¿Qué sentido tiene ella? ¿Su inclusión habría sido insinuada también por el propio confesor? Es prácticamente imposible dar una respuesta categórica a esas interrogantes, pero puede estimarse que la crítica refleja una cierta independencia de la religiosa ${ }^{42}$ Debe tenerse presente que la secuencia de las visiones nos muestra un relato con un comienzo y un final. Así, la narración se abre con el castigo que Nuestro Señor impone al confesor y sigue con la defensa que de él hace la religiosa, que finalmente es escuchada logrando mutar la sanción y satisfaciendo las aspiraciones del sacerdote. Con todo, el texto concluye con la narradora como protagonista. Gracias a ella se reconocen los méritos del confesor y ella misma es recompensada por los seres celestiales con visiones y locuciones que muestran la complacencia de éstos «con sus obras y dolores».

\footnotetext{
${ }^{38}$ Bravo Arriaga, D. 2001: 22.

${ }^{39}$ Donoso, J. 1861. Instituciones de Derecho Canónico: 311. Santiago: Imprenta Nacional. Santiago.

40 Poutrin, I. 1995: 15.

${ }^{41}$ Idem.

${ }^{42}$ No es raro encontrarse con monjas de la época que en la práctica ejercen cierta autonomía frente al confesor, insistiendo en sus puntos de vista o no acatando las instrucciones de este e incluso alterando en parte los roles de cada uno. Situaciones de ese tipo pueden apreciarse en los casos de las monjas chilenas Josefa Peña y Lillo y Úrsula Suárez, ver Araya, A; Azua, X. e Invernizzi, L. 2006. «El epistolario de Sor Josefa de los Dolores Peña y Lillo», en Asunción Lavrin y Rosalva Loreto, eds. Diálogos espirituales. Manuscritos Femeninos Hispanoamericanos. Siglos XVI-XIX: 288 y 297-298 Puebla: Benemérita Universidad Autónoma de Puebla, Universidad de las Américas. Suárez, U. 1984: $149,155,183-184,188,192,220,258$.
} 


\section{Sufrimiento y Purgatorio}

Aquí, nos encontramos con otro de los aspectos interesantes del imaginario de la monja. Este se refiere al significado que tiene para ella el sufrimiento, el dolor, la angustia. En el texto el tema está omnipresente, se le menciona al comienzo cuando la Virgen le indica la sanción que habían decidido imponer al confesor, luego al ofrecerse ella para ocupar su sitio en esa instancia, y más adelante cuando efectivamente el Señor acoge esa petición. Pero, el dolor al cual se alude no sólo es físico, sino que la monja hace también varias alusiones a dolores espirituales, a los desconsuelos en que caía con frecuencia. Ella se siente muy miserable, se refiere a si misma como «un muladar lleno de miserias». ${ }^{43}$ Es una persona que vive con una cierta angustia permanente, ya sea por su relación con el confesor o con la divinidad, y está pensando si ofendió o no al Señor. La monja tenía un sentimiento de culpa, muy propio de la sociedad católica y que se acentúa en la Época Moderna, ${ }^{44}$ el cual se expresaba con más fuerza todavía al interior de los claustros ${ }^{45}$ También, era frecuente que quienes practicaban la oración contemplativa tuvieran una opinión negativa de sí mismos como resultado del proceso de autoconocimiento que los llevaba a asumir sus pecados y miserias cuando se encontraban en la etapa inicial, purgativa, de la aproximación a Dios ${ }^{46}$. Por otra parte, no podemos dejar de considerar la posibilidad de que esas expresiones de auto menosprecio respondan a una retórica que, tras una fingida modestia, busca la benevolencia del lector, al igual que muchos escritores hispanos que recurrían a esa estrategia desde la Edad Media. ${ }^{47}$

Los místicos, en ese proceso de acercamiento a Dios, meditaban sobre sus limitaciones, vicios y pecados y buscaban la purificación con variadas mortificaciones. Al dolor, al sufrimiento, por lo tanto, se le veía como un castigo, como

${ }^{43}$ Revelaciones de un alma piadosa, punto 5.

${ }^{44}$ Delumeau, Jean. 1983. Le péché et la peur. La culpabilisation en Occident XIII-XVIII siècles: cap. 11-18. Paris: Fayard.

${ }^{45}$ Bilinkoff, J. 2005: 12-16.

${ }^{46}$ Puente, L. de la. 1897: t. I, 117-119. Este autor, al referirse a la vía purgativa, necesaria para alcanzar la perfecta pureza, dice que, en el caso de los pecadores, la meditación mueve a la voluntad a que abrace «los actos de conocimiento propio con desprecio de sí mismo..., (ha) tenerse por digno de ser despreciado de todos». En aquella manifestación de humildad extrema no había distinciones entre hombres y mujeres. Por ejemplo, el místico jesuita peruano, Francisco del Castillo, encabeza su autobiografía considerándose «un muladar asqueroso e inmundo». Vargas Ugarte, R. 1960: 1-2. Por su parte, Teresa de Ávila, en la introducción de su autobiografía señala: «El tener padres virtuosos y temerosos de Dios me bastara, sino fuese tan ruin». En otra parte de esa obra agrega: «Para mujercitas como yo, flacas y con poca fortaleza», Vida, Introducción y cap. 11, ${ }^{\circ} 14$.

${ }^{47}$ Weber, A. 1996. Teresa de Avila and the Rhetoric of Femininity: 48-50. Princeton: Princeton University Press.

Hispania Sacra, LXVII

135, enero-junio 2015,247-275, ISSN: 0018-215X, doi: 10.3989/hs.2015.007 
una manera de pagar las culpas y también como una forma de redención, ${ }^{48}$ que le permitía imitar en algo la pasión de Cristo, a la vez que probaba, por voluntad divina, la capacidad para cumplir con las virtudes de la paciencia, humildad y obediencia. ${ }^{49}$ Las ambiciones del confesor son sancionadas por el Señor con la imposición de una enfermedad; la autora del texto tiene muy claro que el padecer dolencias físicas constituye una expiación y que Dios es el juez sancionador. De aquí, probablemente se deriva la inclusión del temor como una de las cuatro virtudes que acompañaban a la monja. De hecho no corresponde a ninguna de las virtudes teologales ni cardinales, pero el temor de Dios sí es uno de los siete dones del Espíritu Santo, que ayudan a seguir los impulsos de Éste y que es expresión de la toma de conciencia de las culpas y del miedo de ofender a Dios. $^{50}$

Relacionado con lo anterior, en el texto ocupa un lugar destacado la presencia de un alma del Purgatorio. La monja tiene la visión de un alma en pena, a la que ve salir de ese confinamiento debido a la acción caritativa de su confesor, que había dicho misas por ella. En el relato, ese suceso constituye una demostración de los valores espirituales del sacerdote y de la valoración que la Virgen le asigna. Al pasar, además la monja menciona que cuando profesó habría visto también salir ánimas del Purgatorio. ${ }^{51}$ Las visiones de este tipo eran muy frecuentes en las visionarias de ese tiempo, fuesen beatas o monjas, y de hecho constituían uno de los temas de mayor recurrencia entre esos fenómenos. Las visionarias con respecto a las ánimas del Purgatorio desempeñaron un papel de intermediarias ante los seres celestiales; transmitían mensajes, tranquilizaban a los deudos y pedían por la pronta remisión de sus culpas. ${ }^{52}$ Para el Perú virreinal existe el diario de una religiosa que da cuenta de las visiones cotidianas que tenía de almas del Purgatorio. ${ }^{53}$ ¿A qué respondía la frecuencia de ese tipo de experiencias entre las místicas? En gran parte es consecuencia del sentimiento de culpa que envolvía a la sociedad. El Purgatorio era un lugar, conceptualmente afinado en la Baja Edad Media, ${ }^{54}$ donde cumplían condena los que habían muerto teniendo a su haber faltas leves o veniales que debían ser purificadas mediante un paso transitorio por él. Pero igual esto implicaba que la masa de condenados era enorme, la gran mayoría de los hombres eran culpables habida cuenta del pecado original. Se creía que sólo una minoría,

${ }^{48}$ Durán, N. 2008. Retórica de la santidad. Renuncia, culpa y subjetividad en un caso novohispano: 230. Ciudad de México: Universidad Iberoamericana.

${ }^{49}$ Lavrin, A. 2005: 30.

${ }^{50}$ Tomás de Aquino, Suma Teológica. P. I-II, c. 68. P. II-II, c. 19.

${ }^{51}$ Revelaciones, op cit., punto 2

${ }^{52}$ Lavrin, A. 2005: 39.

${ }^{53}$ Van Deusen, N. E. (Ed). 2004. The Souls of Purgatory. The Spiritual Diary of a SeventeenthCentury Afro-Peruvian Mystic, Ursula de Jesús. Alburquerque: University of New Mexico Press.

${ }^{54}$ Le Goff, J. 1985. El nacimiento del Purgatorio: 151 y ss. Madrid: Taurus Ediciones. 
la de los inmaculados se iba directamente al Cielo. ${ }^{55} \mathrm{Y}$ además, las penas del Purgatorio eran tan duras como las del Infierno, en donde el fuego cumplía la función expiatoria ${ }^{56}$ En todo caso, la duración de ese castigo podía reducirse si los vivos contribuían con sus suplicas y oraciones a favor de los muertos. En la misma medida que en los siglos XVI y XVII se acentúan los rasgos más aterradores del Purgatorio, se estimula en los fieles la preocupación por las almas que allí permanecen, a las que se considera dignas de compasión. La labor pastoral se expresa en el establecimiento de cofradías, capellanías, fundaciones, en los testamentos, en las oraciones y en las incontables misas dichas en el nombre de ellas.$^{57}$ Desde el siglo XII, con Hugo de San Víctor, se consideraba que si las faltas cometidas por un difunto no eran graves, la misa podía tener gran eficacia en disolverlas. ${ }^{58}$

\section{Rescate de un alma y devociones}

En el texto de la monja, su confesor había dicho un «octavario» de misas por el alma en pena, que finalmente habrían surtido efecto al ver la religiosa como salía de su duro trance.$^{59}$ En la época había una gran preocupación por conocer el destino de los difuntos en el Más allá. A las visionarias, dado su aproximación al mundo sobrenatural, se les interrogaba para que informaran sobre la suerte corrida por personas cercanas e intercedieran por ellas ${ }^{60}$ En la visión de la monja, el alma liberada se mostró en forma «de una garza en extremo alba» y muy resplandeciente, la cual fue depositada por una de las cuatro virtudes en manos de la Virgen. ${ }^{61}$ ¿Qué pueden representar esas imágenes? No era muy frecuente la presencia de la figura de la garza en una escena de carácter reli-

55 Van Deusen, N. E (Ed). 2004: 32.

${ }^{56}$ Delumeau, J. 1983: 427 y ss.

${ }^{57}$ Martínez López-Cano, P.; Von Wobeser, G. y Muñoz, J.G. (Coords.). 1998. Cofradías, Capellanías y Obras Pías en la América Colonial. México: Universidad Nacional Autónoma de México. Ver especialmente los trabajos de Asunción Lavrin, Gisela von Woseber y Cyntia Montero. Las misas y buenas obras nos sólo podían contribuir a la disminución del tiempo en el Purgatorio de un alma determinada, sino también del oferente una vez fallecido. También, Muñoz, J. G. «Las estrategias de una elite frente a la tierra y al cielo: capellanías en Colchagua en el siglo XVIII»: 158-159. Ver además Horvitz, M.E. 2006. Memoria del Nombre y Salvación Eterna. Los Notables y las Capellanías de Misas en Chile 1557-1930: cap. I. Santiago: Departamento de Ciencias Históricas. Universidad de Chile. Kordić, R y Goić, C. 2005. Testamentos coloniales chilenos. Madrid: Universidad de Navarra, Iberoamericana y Vervuert.

${ }^{58}$ Le Goff, J. 1985: 167.

${ }^{59}$ Revelaciones..., op. cit., punto 2.

${ }^{60}$ Millar Carvacho, R. 2009: cap. V. Lavrin, A. 2005: 39.

${ }^{61}$ Revelaciones..., op. cit., punto 2. Era frecuente que las visionarias representaran en sus visiones la estética barroca que recepcionaban a través de los libros e iconografía a la que tenían acceso. Poutrin, I. 1995: 235-238. 
gioso. Sin embargo, desde la Edad Media la cultura cristiana había asignado un papel simbólico muy específico a los animales. A través del simbolismo que encerraban se trataba de interpretar el mundo divino. En ese contexto, las aves, por lo general representaban «la trascendencia en el plano teórico, así como también la espiritualidad»; y era frecuente que se utilizaran para representar a las almas. ${ }^{62}$ Por otra parte, de manera específica la garza, que se le ubicaba en el ámbito de las aves buenas, simbolizaba la generosidad y fidelidad..$^{63}$ A partir de ese lenguaje simbólico, resulta coherente la visión que tiene la monja de una garza representando a un alma liberada del Purgatorio. Esta es mostrada como expresión de fidelidad al Señor, cuya blancura, a su vez es símbolo de la pureza que ahora ostenta.

En el escrito que analizamos, el personaje central de las visiones y locuciones es la Virgen. Ella es la que le informa de lo que ha determinado su Hijo respecto del confesor y es ante ella que la religiosa intenta no sólo revertir la sanción, sino ante la que expone los méritos del sacerdote para que fuese recompensado. En suma, la monja recurre a la Virgen como intercesora ante su Hijo y como protectora ante sus angustias. Lo que acontece con el confesor tiene a la religiosa profundamente inquieta, afligida, porque siente por él gran aprecio y se entera de que el Señor ha decidido castigarlo con una enfermedad. Recurre a la Virgen para que interceda y se modifique esa determinación. Pero luego está el asunto de la retribución que se le hace al sacerdote por su labor caritativa. Esto genera en la monja reacciones encontradas. Por una parte, siente que sus súplicas son escuchadas y por otro se desconsuela por que lo perderá, al tener que trasladarse de ciudad. En uno de los párrafos del texto, la religiosa señala:

«Y como de esto no había evidencia, me culpaba y me afligía y temí no ofender a mi $\mathrm{S}[$ eñ]or y así acogime a la sombra y refugio de mi S[eño]ra y retirándome a mi soledad de mi celda, delante de una imagen de mi S[eñ]or y mi S[eño]ra, me postré pidiéndoles perdón y fuerzas para conformarme si era cierta mi representación o que apartase de mi aquel pensamiento impertinente». ${ }^{64}$

Las angustias de nuestra monja no sólo eran producto de lo que sucedía con su confesor, sino que también estaban asociadas a la conciencia que tenía de sus miserias. En suma, sus aflicciones eran en gran medida consecuencia de la culpabilización que impregnaba su conciencia. Ante esas circunstancias, al igual que muchísimos fieles, la religiosa, posiblemente con más intensidad que el común, busca protección en algunos de los medios que ofrecía la religión

\footnotetext{
${ }^{62}$ Morales Muñiz, M. 1996. «El simbolismo animal en la cultura medieval», en Espacio,Tiempo y Forma. Serie III, Ha. Medieval, t. 9: 242.

${ }^{63}$ Ibídem: 254. Malaxecheverría, I. 2002. Bestiario medieval: 160. Madrid: Ediciones Siruela.

${ }^{64}$ Revelaciones..., op. cit., punto 3.
} 
para tranquilizar o dominar los miedos y angustias. Entre estos sin duda uno de los más recurridos era el culto a la Virgen. Desde fines de la Edad Media se le representa, con la cabeza en el cielo y los pies en la tierra y con el gran manto de la «Gracia» o de la «Misericordia», que cubría a los hombres entregándoles su protección. ${ }^{65} \mathrm{La}$ presencia de San José en el texto también responde en el imaginario religioso de la época al mismo criterio. Era considerado el patrón de la buena muerte y se le valoraba como protector de los peligros que enfrentaban los hombres en la tierra o en la otra vida,${ }^{66}$ amén de que desde los tiempos de Santa Teresa de Ávila se había transformado en un estandarte de la mística, al punto de haber llegado a ser, en palabras del jesuita Jean-Joseph Surin, el patrono de muchas de las almas más significativas del siglo XVII. ${ }^{67}$

\section{REFLEXIONES FINALES}

En una primera impresión pareciera que la monja autora del texto está mediatizada por su confesor, que le ordena poner por escrito unas visiones que tienen que ver con su persona, la que figuraba beneficiada con los favores divinos. Con todo, esa apreciación debe matizarse si los hechos anteriores, que son efectivos, se aprecian desde una perspectiva más amplia, que incluye la mentalidad religiosa de la época y la personalidad de la monja. La persona del confesor era clave en la vida de las monjas y más si se trataba de una mística visionaria. La dirección espiritual generaba vínculos afectivos que trascendían lo meramente religioso, sin que implicaran aficiones deshonestas, aunque a veces podían darse. Por lo general las relaciones que se generaban entre ambos sujetos eran bastante complejas y llenas de matices. Estaban condicionadas por las relaciones de género, por el voto de obediencia, por la autoridad del saber y por los atributos para contactarse con el Más allá. En principio esa relación era muy asimétrica, en desmedro de la religiosa, pero ésta tenía a su favor la aptitud especial para comunicarse con los seres celestiales, lo que en la época les otorgaba un poder enorme del que estaban muy conscientes.

Nuestra monja sentía un gran aprecio por su confesor y estuvo dispuesta a soportar mortificaciones por él y a aceptar perderlo, cuando el Señor lo

${ }^{65}$ Delumeau, J. 1989. Rassurer et protéger. Le sentiment de sécurité dans l'Occident d'autrefois: 281. France: Fayard. En muchos formularios que se utilizaban en los testamentos se ponía la siguiente la frase: «tomando como tomo por mi abogada e intercesora a la serenísima siempre Virgen María, nuestra Señora», ver Kordić, R. y Goić, C. 2005.

${ }^{66} \mathrm{El}$ culto a San José tuvo un gran impulso en el siglo XvII y en su difusión los jesuitas desempeñaron un papel destacado. Delumeau, J. 1989: 340-345.

${ }^{67}$ Certeau, M. de. 1994. La fábula mística. Siglos XVI-XVII: 299-300. México: Universidad Iberoamericana. 
recompensa, en parte merced a su intercesión. ${ }^{68}$ Pero, el texto también deja muy claro justamente esto último, es decir el papel determinante que la religiosa desempeñó en el premio que se le concedió al sacerdote. Ella, con sus suplicas y oraciones, y gracias al vínculo que tenía con la Virgen, logró que el Señor reconociera los méritos de su confesor. Ella desempeña una labor muy activa. El texto resalta su persona. La Virgen la estima, la valora, le encarga que le gane almas para su Hijo. Ante eso ella le hace una pregunta que puede tener varias lecturas y que refleja a una persona consciente de sí misma y de las limitaciones de su condición: «Madre mía el cómo darte las almas, ignoro, por no ser confesor, ni poder predicar» ${ }^{69}$ No era del todo infrecuente encontrarse con expresiones de ese tipo por parte de monjas escritoras y místicas. Asumían las cortapisas que les imponía su estado, pero al mismo tiempo se sabían poseedoras de capacidades y privilegios de los que carecían los sacerdotes.$^{70}$ La monja que analizamos participa de esa mentalidad y en el texto deja en claro su poder, más allá de sus miserias y condición femenina, al exponer que el premio a su confesor se logró por su mediación y al hacer hincapié de que gozaba de la confianza de los seres divinos. Puede considerarse que en esta relación ambas partes sacan provecho en la medida que el confesor obtiene lo que quería y la monja deja de manifiesto que ella es la gestora de ese logro y que goza del favor de los seres celestiales. ${ }^{71}$

La protagonista de las visiones y locuciones que tiene la monja es la Virgen. En los diálogos que mantienen queda reflejado un determinado imaginario que corresponde a la mentalidad religiosa de esos años. Los temas e imágenes que aparecen responden a las inquietudes, creencias y comportamientos que formaban parte del acervo mental de los hombres de la época. Por lo mismo, gozaban de credibilidad. Si la monja tenía buena fama, era en extremo piadosa y practicante regular de la oración contemplativa, el gozar de dones extraordinarios, como las visiones y las locuciones no podían resultar extraños. Además, el confesor avalaba la veracidad de lo que experimentaba.

En las locuciones quedan de manifiesto las angustias y los dolores de la religiosa. La Virgen es quien la protege, le da amparo y recibe sus suplicas. Es la intercesora ante su Hijo. La monja se siente culpable, en último término de ser

${ }^{68}$ Una muestra de los complejos vínculos, sobre todo en el ámbito espiritual, que se producían entre una religiosa y su confesor se puede ver en Myers, K.A and Powell, A. (Eds.). 1999: 316 - 324.

${ }^{69}$ Revelaciones..., op. cit., punto 1.

${ }^{70}$ La monja Francisca de la Natividad, del convento de carmelitas descalzas de Puebla de Los Ángeles, dice en su autobiografía: «tengo una envidia santa a los que se ejercitan en la conversión de las almas y solo por esto quisiera haber sido hombre», Loreto, R., «Escrito por ella misma. Vida de la madre Francisca de la Natividad», en Lavrin, A. y Loreto, R. 2002: 49.

${ }^{71}$ Una autora, exagerando el punto, habla de la mutua manipulación que podía darse entre el confesor y la monja en las peculiares relaciones que se generaban entre ambos, Ranft, P. 1994: 22-24. 
pecadora, y pide misericordia, no sólo para ella, también para su confesor. Se muestra una relación de premios y castigos. La Virgen la protege enviándole las virtudes y la premia con flores, pero también permite que su Hijo le envíe una enfermedad porque «quería gratar contigo y esperaba verte afligida». ${ }^{72}$ ¿Qué se valoraba de la monja? El entregar completamente su voluntad al Señor, estar dispuesta a sufrir por ganar corazones, es decir, almas para el Señor. La Virgen ocupaba el centro, porque era la protectora por antonomasia y al mismo tiempo la intercesora ante su Hijo para aminorar las sanciones y premiar las acciones de caridad, que eran expresiones del amor a Cristo.

\section{BiBLIOGRAFÍA}

Alcalá, Ángel. 1984. «Control de espirituales», en Joaquín Pérez Villanueva y Bartolomé Escandell Bonet (Dirs.) Historia de la Inquisición en España y América: T. I, 780-842. Madrid: Biblioteca de Autores Cristianos.

Andrés, Melquíades. 1984. «Alumbrados, erasmistas, «luteranos» y místicos, y su común denominador: el riesgo de una espiritualidad más «intimista», en Ángel Alcalá (Ed.), Inquisición española y mentalidad inquisitorial: 373-409. Barcelona: Ariel.

Andrés, Melquíades. 1994. Historia de la mística de la Edad de Oro en España y América. Madrid: Biblioteca de Autores Cristianos.

Araya, Alejandra; Azua, Ximena e Invernizzi, Lucía. 2006. «El epistolario de Sor Josefa de los Dolores Peña y Lillo», en Diálogos espirituales. Manuscritos Femeninos Hispanoamericanos. Siglos XVI-XIX. Asunción Lavrin y Rosalva Loreto, eds. Puebla: Benemérita Universidad Autónoma de Puebla, Universidad de las Américas.

Arenal, Electa \& Schlau, Stacey. 1989. Untold Sisters. Hispanic Nuns in Their Own Works. Alburquerque: University of New Mexico Press.

Bilinkoff, Jodi. 2005. Related lives. Confessors and Their Female Penitents, $1450-$ 1750. Ithaca: Cornell University Press.

Borda, Fr. Andrés de. 1708. Práctica de confesores de monjas, en que se explican los cuatro Votos de Obediencia, Pobreza, Castidad y Clausura, por modo de Diálogo. México: Francisco de Ribera Calderón.

Borriello, L.; Caruana, E.; Del Genio, M.R. y Suffi, N. 2002. Diccionario de mística. Madrid: Editorial San Pablo.

Bravo Arriaga, Dolores. 2001. El discurso de la espiritualidad dirigida. Antonio Núnez de Miranda, confesor de Sor Juana. México: Universidad Nacional Autónoma de México.

${ }^{72}$ Ibídem., punto 3.

Hispania Sacra, LXVII

135, enero-junio 2015,247-275, ISSN: 0018-215X, doi: 10.3989/hs.2015.007 
Certeau, Michel de. 1994. La fábula mística. Siglos XVI-XVII. México: Universidad Iberoamericana.

Delumeau, Jean. 1983. Le péché et la peur. La culpabilisation en Occident XIII-XVIII siècles. Paris: Fayard.

Delumeau, Jean. 1989. Rassurer et protéger. Le sentiment de sécurité dans l'Occident d'autrefois. France: Fayard.

Donahue, Darcy. 1989. «Writing Lives: Nuns and confessors as auto/biographers in Early Modern Spain». Journal of Hispanic Philology. 13: 230-239.

Donoso, Justo. 1861. Instituciones de Derecho Canónico. Santiago: Imprenta Nacional.

Durán, Norma. 2008. Retórica de la santidad. Renuncia, culpa y subjetividad en un caso novohispano. Ciudad de México: Universidad Iberoamericana.

Epistolario de Sor Dolores Peña y Lillo (Chile, 1763-1769). 2008. Raïssa Kordić (Ed.). Frankfurt: Editorial Iberoaméricana y Vervuert. Frankfurt.

Fernández, Amaya; Leiva, Lourdes; Guerra, Margarita y Martínez, Lidia. 1997. La mujer en la conquista y la evangelización en el Perú (Lima 1550-1650). Lima: Pontificia Universidad Católica del Perú.

Haliczer, Stephen. 2002. Between Exaltation and Infamy. Female Mystics in the Golden Age of Spain. New York. Oxford University Press.

Horvitz, María Eugenia (Dir.) 2006. Memoria del Nombre y Salvación Eterna. Los Notables y las Capellanías de Misas en Chile 1557-1930. Santiago: Departamento de Ciencias Históricas. Universidad de Chile.

Huerga, Álvaro. 1978-1994 Historia de los Alumbrados. I.- Los Alumbrados de Extremadura (1570-1582). Historia de los alumbrados. V.- Temas y personajes (15701630). Madrid: Fundación Universitaria Española.

Ibsen, Kristine. 1999. Women's Spiritual Autobiography in Colonial Spanish America. Gainesville: University Press of Florida.

Kordić, Raïssa y Goić, Cedomil. 2005. Testamentos coloniales chilenos. Madrid: Universidad de Navarra, Iberoamericana y Vervuert.

Krynen, Jean. 1990. Saint Jean de la Croix et l'aventure de la mystique espagnole. Toulousse. Presses Universitaires du Mirail. France-Iberie Recherche.

Lavrin, Asunción y Loreto, Rosalva (Eds.). 2002. Monjas y beatas. La escritura femenina en la espiritualidad barroca novohispana. Siglos XVII y XVIII. México: Universidad de las Américas. Puebla y Archivo General de la Nación.

Lavrin, Asunción. 1993. «La vida femenina como experiencia religiosa: biografía y hagiografía en Hispanoamérica colonial». Colonial Latin American Review 2: 27-51.

Lavrin, Asunción. 2005. «La madre María Magdalena Lorravaquio y su mundo visionario», Signos Históricos, 13: 22-41. 
Lavrin, Asunción. 2008. Brides of Christ. Conventual Life in Colonial Mexico. California: Stanford University Press.

Lavrin, Asunción. 2012. «La religiosa y su confesor. Epistolario de una clarisa mexicana, 1801-1802, Archivum Franciscanum Historicum, 105: 455-478.

Lehfeldt, Elizabeth A. 2005. Religious Women in Golden Age Spain. The Permeable Cloister. Hampshire: Ashgate.

Le Goff, Jacques. 1985. El nacimiento del Purgatorio. Madrid: Taurus, Madrid, 1985.

Malaxecheverría, Ignacio. 2002. Bestiario medieval. Madrid: Ediciones Siruela.

Márquez, Antonio. 1980. Los alumbrados. Orígenes y filosofía (1525-1559). Madrid: Taurus Ediciones. Segunda Edición.

Martínez López-Cano, Pilar; Von Wobeser, Gisela y Muñoz, Juan Guillermo (Coords.). 1998. Cofradias, Capellanías y Obras Pías en la América Colonial. México: Universidad Nacional Autónoma de México.

Méndez, Luz María. 1992. «José Toro y Zambrano 1674 - 1745 - 1760», en C. Oviedo Cavada (Dir.) Episcopologio chileno 1561-1815, t. IV, 347-384. Santiago: Ediciones Universidad Católica de Chile.

Millar Carvacho, René. 2009. Santidad, falsa santidad y posesiones demoníacas en Perú y Chile. Siglos XVI y XVII. Santiago: Ediciones Universidad Católica de Chile.

Morales Muñiz, Ma. Dolores-Carmen. 1996. «El simbolismo animal en la cultura medieval». Espacio, Tiempo y Forma. Serie III, Ha. Medieval, 9: 229-255.

Muriel, Josefina. 1994. Cultura femenina novohispana. México: Universidad Autónoma de México.

Myers, Kathleen A. and Powell, Amanda (Eds.). 1999. A wild country out in the garden. The Spiritual Journals of a Colonial Mexican Nun. Bloomington: Indiana University Press.

Oviedo Cavada, Carlos. 1979. Los obispos de Chile 1561-1978. Santiago: Editorial Salesiana.

Oviedo Cavada, Carlos. 1982. «La defensa del indio en el sínodo del obispo Azua de 1744», Historia 17: 281-354.

Owen, Sarah. 2014. «Monjas españolas en Filipinas: La formación de lectura y escritura de Sor Ana de Cristo», en Baranda, N. y Marín M.(Eds) Letras en la celda. Cultura escrita en los conventos femeninos en la España moderna. Madrid-Frankfurt: Iberoamérica- Vervuert.

Poutrin, Isabelle. 1995. Le voile et la plume. Autobiographie et sainteté femininé dans la l'Espagne moderne. Madrid: Casa de Velázquez.

Puente, Luis de la. 1897 (1609). Meditaciones espirituales. Barcelona: Imprenta y Librería de Subirana Hermanos. 
Ranft, Patricia. 1994. «A Key to Counter Reformation Women's Activism: The Confessor-Spiritual Director». Journal of Feminist Studies in Religion, Vol. 10, № 2.

Rossi de Fiori, María; Caramella de Gamarra, Rosanna; Martínez de Lecuona, Soledad y Fiori Rossi, Helena, 2008. La palabra oculta. Monjas escritoras en la Hispanoamérica colonial. Salta, Argentina: Universidad Católica de Salta, Editorial de Textos Universitarios.

Santa Teresa de Ávila. 1977. Libro de la vida, en Obras Completas. Burgos: Editorial «Monte Carmelo».

Santo Tomás. 1954-1960. Suma Teológica. Biblioteca de Autores Cristianos

Suárez, Úrsula. 1984. Relación autobiográfica. Santiago: Academia Chilena de la Historia.

Urrejola, Bernarda. 2006. «<Carísimo padre mío y toda mi estimación en Nuestro Señor >: Obstinación y afecto por el confesor en el epistolario de Josefa de los Dolores Peñailillo (Chile, s. XVIII)». Atenea 494: 67-82.

Van Deusen, Nancy E. 2004. The Souls of Purgatory. The Spiritual Diary of a Seventeenth-Century Afro-Peruvian Mystic, Ursula de Jesús. Alburquerque: University of New Mexico Press

Weber, Alison. 1996. Teresa de Avila and the Rhetoric of Femininity. Princeton: Princeton University Press. 


\section{ANEXo DOCUMENTAL}

\section{Revelaciones de un alma piados*}

1. S[eñ]or. V[uestra] s[eñoría] me manda asiente lo que ya le tengo comunicado, ya que dudo si iré hablando con v[uestra] s[eñoría] o dando solo razón de lo que mi S[eño]ra y madre me ha dado a entender en estos tiempos. Y, por no dilatarme en obedecer, comienzo de cualquier suerte, fiada de que v[uestra] s[eñoría] me entiende y solo a mi S[eño]ra pido alumbre a su Hijo y a mi para obedecer con acierto.

Lo primero con que me favoreció mi S[eño]ra fue a fines de enero de este de 174 cinco, estando ofreciendo mis pobres oraciones por la salud de un bienhechor mío a este tiempo se me hizo patente mi Madre y Señora diciéndome:

María, hija, yo quiero disponer a tu confesor con una prolija enfermedad que ha determinado mi hijo y tu esposo, padezca por espacio de tres meses y así dispón tu voluntad para este golpe.

A esto dije, en todo se haga su santa voluntad y la vuestra, pero mamita no me lo quite mi s[eñ]or. Ayudádmelo a pedir que aquí no llegan mis flacas fuerzas. A esto respondiome uno de mis compañeros y díjome compañera fía en el S[eñ]or y en su Santísima Madre. Aquí no entendí nada solo recibí esto como enseñanza de esta voz de mi compañero... y en las razones de mi S[eño]ra las recibí como aviso, que en la realidad lo fue, pues a los dos días me avisaron como había caído muy malo, de repente, mi padre y señor. Esta noticia me trajeron sábado acabando yo de comulgar. Aquí me hice cargo de la falta que a su casa hacía y a mi pobre alma, que uno y otro llenó mi corazón de congoja y así fuíme a mi S[eño]ra y postrada dije: S[eño]ra mía si al cabo de los tres meses me has de prestar a mi padre hágase tu santa voluntad y dádmele aliento y conformidad y acierto al médico que me dicen le asiste. Por lo cual ofrezco mamita todos mis huesos y nervios a que mi S[eñ]or descargue en ellos todo aquello que en mi confesor determina padezca en aquellos tres meses y siendo esta su santa voluntad pedí no se dilatase en mi. Así fui diciendo.

Aquí me dijo mi S[eño]ra:

Hija, ¿no me has dicho que le quieres llorar muerto y no abrumado con cargos?

Aquí, sin entender lo que ahora, dije sí Señora, sí he dicho, porque temo se malogren tus asistencias y empeños de tus misericordias; pero como te veo que cada día

\footnotetext{
* Se ha modernizado la ortografía y la puntación. Además, entre corchetes se incluyen las letras que completan las abreviaturas originales. En aquellos casos en que una palabra está escrita de manera incorrecta en el original se agrega entre paréntesis el adverbio sic. Los párrafos que aparecen subrayados están así en el manuscrito.
} 
me lo a prohíjas con más favores y amor por hijo, esto mismo me alienta a pedírtelo de limosna, pues tengo a mi mamita para que me lo ampare y llene de auxilios. Entonces dijo mi Reina: Anda hija que tu fe será premiada con el despacho de tus peticiones. Cargaraste (sic) un mes de tormentos y dolores que correspondan a los tres con que mi Hijo y tu esposo, a petición mía, le queríamos despertar del letargo en que le tiene la esperanza de ser príncipe. Y para esto te hago saber que estaba determinado que, en brazos de la muerte, lograse sus esperanzas. Y pues nos lo pides, hoy le tienes, cuidad de sus aciertos. Aquí desaparece mi S[eño]ra dejándome llena de consuelo por prestármelo, pero dudando en el cargo que se me hacía. Y estando como dormida o fuera de mi, como dije, oí a mi S[eño]ra y madre que me dijo: hija no pongas duda en el apartamiento que te propones, porque ya se cumplió la voluntad del Altísimo en tu confesor y yo te he querido disponer con este aviso del ruido que hizo en tu corazón el de su cabeza, que ya llevaba en su interior la noticia del despacho de su pretensión mi Hijo y tuyo.

Aquí quedó suspensa mi alma deseando no apartarse un instante de hacer gustosa la voluntad de mi S[ño]ra y así dije: Madre mía, deseo con todo mi corazón se haga en mi vuestra santa voluntad y doite (sic) gracias porque así has alentado mi alma con hacerle entender que se ha cumplido la voluntad del Señor, quien no puede errar en sus disposiciones. Y así amparármelo Señora y dádmele luces de auxilios en el gobierno de las almas, que así se alentará la mía en su desamparo y soledad. Aquí me detuvo mi S[eño]ra y mi madre diciéndome: déjate M[arí]a no cuides de ti, que yo soy dueño de las voluntades y solo quiero que des almas y ese sea tu desvelo.

Dije: Madre mía el cómo darte las almas, ignoro, por no ser confesor, ni poder predicar; si mi padre y señor te las ha de dar, cuanto antes quitádmelo, aunque mi natural, amigo de su alivio, reviente; váyase en hora buena que yo le ayudaré desde acá con lo que vos, mamita, me dieses; y desde ahora te ofrezco cuanto sintiere y padeciere... Todo por sus aciertos. Y te pido que cuando yo viere a mi padrino no te ofendas de que yo muestre sentimiento. Y así, si ha de haber en esto afecto, destiérralo de mí S[eño]ra, q[ue] yo no deseo más que obedecer.

Aquí me dijo mi Reina: anda hija, que no se ofende tu esposo de que seas agradecida; ni temas que te castigue, como dices, en dividir los cuerpos, porque antes le agradarás en tener siempre rendida tu voluntad a su querer, que en esto harás la nuestra, pues yo te puse en sus manos para que se vean.

2.- Jesús, M[arí]a y Joseph, guíen mi pluma para que por obediencia no oculte yo lo que no es mío, sino que de misericordia se me da a entender como favorece el S[eño]r a las almas que escoge para sí y de paso enseña a la mía.

Y aquí digo que estando el día cinco de abril sumamente consolada por que este día había favorecido el S[eño]r a mi alma con que viese aquella mañana salir un alma que tantos años estaba en penas. Y a este consuelo de mi alma se 
le aumentó con ver que había tenido parte mi confesor con su mucha caridad; y que por esta alma había dicho un octavario de misas y en la postrera que dijo en el altar de nuestra S[eño]ra, oyéndola yo, ví que al consumir, le entregó a nuestra $\mathrm{S}$ [eño]ra el alma de esta pobre necesitada. Y todo mi consuelo fue por que vi como mi Señora le pagó esta caridad por entonces; porque, en inter que estaba diciendo misa, lo vi acompañado de cuatro virtudes, que éstas, ya he dicho, tienen sus nombres y formas de personajes, con que mi Madre me las tiene a mi vista para que me acompañen a mí. Y estas mismas fueron las que le acompañaron con luces en las manos y estas iban acompañando y poniendo en manos de mi S[eño]ra unas flores y cada flor se convertía en las manos de mi Señora en un rayo de luz que despedía con presteza sobre este mi confesor, pagándole luego su caridad, que así lo entendí = con auxilios....

Luego vi que uno de aquellos personajes llevó el alma por quien se había ejercitado aquella caridad y la puso en manos de esta gran Reina. La alma iba en forma de una garza en extremo alba y tan resplandeciente que me llevó toda la atención y me dejó llena de deseos de seguirla o de saber agradecer estos favores. Y así, en el modo que pude, dí gracias a mi S[eño]ra. Y a este tiempo oí una voz, como que salía de esta garza, que decía: el altísimo pague esta caridad. Y desapareciose (sic) todo porque se acabó la misa. Desta (sic) misma forma vi, cuando profesé, a las almas del Purgatorio y con esta misma razón se despidieron de mí.

Esto fue lo que este día cinco de abril me sucedió por la mañana, que todo lo referido causó a mi alma gran consuelo; pero duróme (sic) sólo hasta la tarde, porque entonces dispuso el S[eñ]or se mezclase el gusto....

3.- Y fue de esta suerte, estando en mi oficio de puerta, oí pasar por la calle una caleza, que no era tanto su estruendo, cuanto hizo en mi corazón, porque conocí era la de mí confesor y mí padre en el S[eñ]or. Y esta parece que con la novedad de pasar sin llegar donde yo estaba, sería por haber estado conmigo por la mañana hallaba novedad en esto y más cuando pregunté a una que dentraba (sic) de fuera si era mi padre y señor el que había pasado y esta me aseguró que lo era. Aquí sin más luz que esta, de repente se cercó mi corazón de tan gran tristeza, que en aquel lugar me corregía interiormente y afligía de ver mi poca virtud en resistir un mero ofrecimiento, con que me di yo sola la noticia, que llevaba en su pecho mi confesor cuando pasó. Y como de esto no había evidencia, me culpaba y me afligía y temí no ofender a mi S[eñ]or. Y así acogíme (sic) a la sombra y refugio de mi S[eño]ra y retirándome a mí soledad de mí celda, delante de una imagen de mi S[eñ]or y mi S[eño]ra, me postré pidiéndoles perdón y fuerzas para conformarme si era cierta mi representación o que apartase de mí aquel pensamiento impertinente.

Aquí fue adonde mi S[eño]ra, con sus acostumbradas caricias, favoreció mi alma con esta pregunta diciéndome: ¿María hija, deseas hacer la voluntad del Altísimo? 
A esto dije, sí S[eño]ra, dándome voz para ello vuestra Santísima gracia, hágase en mi tu santa voluntad, quedándome, a mi parecer, como fuera de mí y en manos de mi S[eño]ra. En ti mis misericordias y que me labres corazones para hacerlos depósitos dignos de los designios del Altísimo y este es el modo de darme almas, como has dispuesto a ésta, en quien se hubieran borrado si tu no le sacas del riesgo. Y así yo te lo entregué, haciéndote patente sus necesidades, no para apartarte de él hasta que lo veas en mí. Y pues a este te entregué también a ti para que te ayude y guíe. No les divido el cuidado, más que meramente el cuerpo. Y asi quita temores hija que esto te hacen perder tiempo y vete a tu oficio, que presto se dirá lo que tu dices sospechar y que es mero ofrecimiento. No es hija como tu dices, sino que yo te lo he dado a entender para alumbrarte, como te quiero vengas a mi con tus dudas, que yo también quería gratar contigo y esperaba verte afligida.

Dejo muchas razones de mi S[eño]ra, llenas de caricias, con que me dejó avisada de esta divina disposición y de paso me manifestó su santa voluntad dándome con ella una grande enseñanza. Y acabose todo, vuelta ya en mi, fuíme (sic) a mi oficio a esperar la noticia, que ya yo no ignoraba y esta la trajeron dentro de una hora y quedé segura de mis recelos.

4.- Prosigo obedeciendo y digo que estando el día siete de abril ofreciendo mis tibias oraciones por los aciertos de mi padre y señor, a este tiempo vi a mi Señora con un corazón en las manos, con unas cruces, a mi parecer de bronce, pero con ser tantas y de peso no le rendían ninguna.

A esto me dijo mi S[eño]ra:

María hoy he querido premiar la caridad de tu confesor. Y mi Hijo, por ser día miércoles, en que se dedica a consolarte y sacarte de dudas con que veas su corazón en mis manos, el día mesmo (sic) que se le hace saber le ha elegido el Altísimo por pastor de las almas. Y aunque le ves estas cruces, como me pides le ayude, yo le fortalezco y así aliéntale, que yo le asisto. Y acudiendo a mí no le abrumarán las cruces, que estas no le han de faltar. Y tú no te consuelas con que vaya a esta ciudad que tiene por título el misterio que tú amas. Y así hija las dos hemos de enderezar esta ciudad. ¿Y tú no le prestas tus compañeros, como yo te los presté para que te enseñasen y apartasen de los riesgos?

A esto dije, aquí está vuestra esclava, yo no tengo querer ni no querer, sino que deseo hacer la voluntad de mi S[eño]r. Y así hágase en todo, que bien sabe mi esposo y señor como deseo ayudarle con la sangre de mis venas. Y al instante que razoné estas palabras, me dijeron mis compañeros, amor y caridad y el temor: desde hoy resguardamos su corazón sin hacerte falta a vos. De que quedé sumamente consolada y agradecida a estas misericordias y promesas. Vendigámosle para siempre. 
Y van las razones que no pude decir en el confesionario y a Dios.

5.- Vuelvo a proseguir por obediencia y pido a mi S[eñor]ra luz para el acierto, por que confieso de mi que esto se me ha mandado asentar cuando más ofuscadas y oscuras tengo las potencias; y, si temores me cercan otras veces, ahora me tienen fuera casi de mí. En todo se haga la voluntad de mí S[eño]r y comienzo en su presencia.

Y digo que estando cumpliendo el mes que me aceptó mi S[eño]ra de padecer dolores por la salud de mi confesor y padre en mi s[eño]r; y, como fueron tan vehementes, flaquearon las fuerzas y me rindieron a una cama, donde me cogió el día de mi s[eño]r y padre san Joseph. Y fue santo el deseo que tuve de ir a misa y visitar en el coro a mi santo padre y s[eño]r San Joseph, que parece que el alma salió de su centro, que sólo me alentaba el considerar que la caridad y misericordia de mi S[eñor]a me tenían imposibilitada. Y así desahogaba mi corazón con ofrecerle al santo mis deseos y padeced con mis dolores. Y así los iba uniendo con los dolores y gozos del santo y pidiéndole con especialidad amparasen todos tres, J[esú]s, M[arí]a y J[osé], a mi confesor pues era este el día de su nombre y como era este el caudal que al presente se me daba, sin otro, esté unido con los méritos del santo, pedí por los aciertos de mi confesor. Y con esta ocupación se me divirtió el desconsuelo que tenía de ver que no me podía hacer fuerza para ir a misa. Estando hablando de esta suerte con mis s[eño]res, vi a este tiempo un género de resplandor que me sacó fuera de mí. Y a este tiempo me hallé presente y vi a mí S[eño]ra con mí S[eñ]or, como de dos o tres a[ñ]os, y a mí padre San Joseph, todos tres como a la porfía me franqueaban sus misericordias, llenas de caricias, las cuales alentaron mi alma, aunque siempre puestos los ojos en mí miseria. Di gracias a mí S[eñ]or y Señora y a mi padre San Joseph por este beneficio. Y ofrecí segunda vez mis pobres oraciones y corto padecer. Todo por los aciertos de mi confesor, como he dicho. Por que me cogió su día con este cuidado entre manos. Aquí fue donde me favoreció mi S[eñ]or, por intercesión de mi s[eñ]or San Joseph, con que yo, miserable, viese el valor que se le había dado a mis obras y dolores haciéndomelas patentes y que yo viese lo que alcanzaban las almas por ellas. Y esta, por quien había trabajado este tiempo, haciéndomelo presente al lado de mi S[eño]ra. Y luego vi a mis cuatro compañeros venir. Dos con luces en las manos y otros dos con unas toallas. El uno traía un cofre, a mi parecer, cubierto con la toalla, y el otro traía como un azafate, también cubierto con la toalla. Estos llegaron a mí. Y el amor y la caridad me dijeron: el S[eño]r quiere hoy alentarte con que se te descubran tus obras y así descubre esos velos, que eran las toallas, y hallarás tu grabado ya hermoseado. Y con valor aquí me postré conociendo mis miserias y errores. Me alentó mi S[eño]ra diciéndome:

Hija, aliéntate y descubre tu grabado. Entonces vi que me alumbraron para descubrir el cofre y en él hallé unas flores tan hermosas, cada una con su rótulo del día que había padecido. Esto vi brevemente y no hay 
razones para explicar el consuelo de mi alma y deseos de padecer por las almas, que con esta vista me quedó.

Luego vi que estas flores eran puestas en manos de s[eño]r San Joseph y el santo se las pasaba a mi Señora. Y mi reina se las presentaba a mi S[eño]r niño, el cual las recibía con agrado y dijo: Estas flores se han dedicado para este ministro mío, y así, para consuelo de esta criatura (poniendo los ojos en mi), dijo:

Adórnenle hoy en su presencia a su confesor, que ya es tiempo y día de su devoción. Entonces con presteza se llegó a mi la obediencia y medió la luz que tenía en la mano y díjome: con esta luz que se te da atiende y ama a las almas, y no me dijo más.

Luego cogió del azafate una ropa blanca y me dijo el temor: Esta le he formado yo, a peticiones tuyas, y el me acoja a mi. Y luego se le puso sobre esta otra azul y esta, me dijo el amor: Yo he formado este ropaje y se lo resguardaremos, si nos da acogida en su corazón, pues así lo dispone nuestra Reina y tu Madre para premiar a los dos su devoción por el grande amor que a su criaturas tiene. No me dijeron lo que contenían estos colores blanco y azul. Y así preguntéselo a mi Señora, la cual me dijo:

Hija, bástate saber que el temor le vista de blanco y no ignoras que es pureza ese color. Y el azul se le pone para resguardo de mi amor. Esto contiene hija los dos colores. No conviene entiendas más -sino en trabajar, porque no deslustre (sic) estas vestiduras que tan hermosas te parecen. Luego llegó la caridad y le puso otra vestidura nácar o carmesí, más larga que todas. Esta no entendí entonces, ni la pregunté por entonces, porque luego me fueron dando las flores que vi primero para que yo ayudase a adornar a mi confesor.

Entonces dije: yo no se mamita a donde he de aplicar estas flores. Y así tu misericordia y mi s[eño]r San José las repartan, pues les han dado el valor y me han favorecido con aceptar mis pobrezas; mi deseo no se ocultará a mi S[eño]r. Luego que razoné esto vi adornar un corazón y entregárselo a mi confesor. Más no entendí que corazón fuese éste, ni me lo dijo mi Reina y pareciome que con solo el tacto de este corazón que digo quedó adornado mi confesor con todas las flores, sin ver yo quien se las pusiese. Ni menos hacía falta ninguna del cofre. Estando yo dudosa si sería este corazón el de mi confesor, me dijo mi S[eño]ra: no conviene hija esto por ahora. Y cubriose todo con un velo y desapareció todo.. dejando mi alma llena de consuelos por una parte y por otra confundida de ver tantas misericordias hechas y extendidas en un muladar lleno de miserias como yo. Y así compadézcanse de mí, que ya me hallo despojada de lo que no era mío por ingrata y mal correspondida. Y así cuidado que por allá no hemos de ver todos y serán juzgados estos beneficios, que creo no se hacen a todos, -ni acaso. 